\title{
Coordination(?) between Branches of Economic Policy across Euro Area*
}

\author{
Kristóf Lehmann - Olivér Nagy - Zoltán Szalai-Balázs H. Váradi
}

In our study we present the coordination between the two main pillars of economic policy - monetary policy and fiscal policy - across the euro area. Growth in the euro area has noticeably decelerated in the past three decades, meaning the economy of the euro area has departed significantly from the logic of the Maastricht criteria. In addition, the lack of a common budget at euro area level and the fact that the oft-conflicting rules overlook sectoral interrelationships also point to the existence of a systemic problem. The difficulties have become increasingly evident in recent years as even the ultra-loose monetary policy has failed to stimulate economic growth significantly. This adverse process was intensified further by fiscal policy, which was intended to be consistent with the fiscal rules formulated in line with Maastricht criteria and can be considered tight, overall, at the euro area level. In recent months, even the policymakers of the European Central Bank have embarked on an open debate with regard to the role of policy branches. In the current political and legal framework, the ECB may be left with limited leeway for easing monetary conditions. In light of all these factors, there may be a need for a more active fiscal policy to stimulate the euro area economy, which, however, may sharpen the debate between the policymakers of individual Member States.

Journal of Economic Literature (JEL) codes: E52, E62, E63, F45

Keywords: monetary policy, fiscal policy, economic policy coordination, Maastricht criteria

* The papers in this issue contain the views of the authors which are not necessarily the same as the official views of the Magyar Nemzeti Bank.

Kristóf Lehmann is a Director at the Magyar Nemzeti Bank.E-mail: lehmannk@mnb.hu Olivér Nagy is an Analyst at the Magyar Nemzeti Bank. E-mail: nagyoli@mnb.hu

Zoltán Szalai is a Senior Economic Expert at the Magyar Nemzeti Bank. E-mail: szalaiz@mnb.hu

Balázs H. Váradi is a Head of Department at the Magyar Nemzeti Bank. E-mail: varadib@mnb.hu

The authors wish to thank Ábel Bagdy, Flóra Balázs and Krisztina Füstös for their valuable observations and active contribution to the preparation of this study. All remaining mistakes are the responsibility of the authors.

The Hungarian manuscript was received on 20 December 2019.

DOI: http://doi.org/10.33893/FER.19.1.3764 


\section{Introduction}

Growth in the euro area has decelerated perceivably in the past three decades, with inflation also stabilising at a low level. As a result, the euro area economy has deviated sharply from the logic of the Maastricht criteria approved in 1992. While this suggests a systemic problem, it was concealed by the existing institutional system for a long time. In light of vastly diverging convergence experiences the question rightfully arises: how did the fiscal rules - which were formulated in accordance with the Maastricht criteria (the pre-condition for euro area accession) and the fiscal conditions thereof - fail to ensure long-term economic growth? One of the shortcomings of the criteria is that, by nature, they do not directly measure the level of harmonisation between financial and economic cycles, the convergence of the real economy and the similarities between economic structures, the significance of which was underpinned by the experiences of the protracted euro area crisis (Nagy - Virág 2017).

The difficulties have become increasingly evident in recent years as even the ultraloose monetary policy failed to stimulate private sector investment notably. The process was intensified further by fiscal policy, which became tighter than necessary in the euro area as a whole. This is leading to growing conflicts, strengthening the tensions between "northern" and "southern" European countries. In an unprecedented development, even the policymakers of the European Central Bank (ECB) have embarked on an open debate in recent months with regard to the optimal allocation of tasks between monetary policy and fiscal policy. The comprehensive monetary easing package adopted by the Governing Council of the European Central Bank in September 2019 in response to the deteriorating business climate indicators and inflation outlook was a sign of this dissent. The step was not supported by all policymakers; in fact, several members of the Governing Council sharply criticised the adopted measures in the media (Weidmann 2019; Knot 2019a). In the current environment, the additional stimulating effect on the economy of the ECB's step can only be moderate; moreover, looking forward, in the event of a further deterioration in the outlook it may leave the euro area's central bank with limited ease monetary conditions further in the current political and legal framework. In light of all these developments, there may be a need for a more active role of fiscal policy to stimulate the euro area economy, which, however, may sharpen the debate between the policymakers of individual Member States.

The monetary policy measures of recent years and the diminishing leeway suggest that, in the current legislative and political framework, monetary policy has come close to exhausting its potential. Accordingly, an increasing number of the European Central Bank's policymakers have underlined in recent months that due 
to the limitations of monetary policy, euro area countries with sufficient leeway should contemplate adopting fiscal stimulus measures to spur economic growth. Some policymakers consider the creation of an euro area-level fiscal framework desirable in order to stabilise the economy of the area over the long term. Those voicing this opinion include Mario Draghi, serving as President of the ECB until the end of October 2019, and his successor, Christine Lagarde. In our study we examine potential developments in the coordination between economic policy branches across the euro area and the extent to which there is room and willingness for closer coordination and the adoption of a more active fiscal policy. Parallel to this we also attempt to cast light on the problems stemming from the existing fiscal rules.

\section{Limited monetary policy leeway}

As a result of the remarkable easing of the monetary stance in post-crisis years, the policymakers of the ECB cut the key policy rate to extremely low levels before adopting - somewhat later than other central banks - significant quantitative easing measures. Although the net asset purchases of the central bank came to a close in December 2018, in view of the deceleration observed in the euro area and the renewed intensification of downside risks, in September 2019 the Governing Council of the ECB adopted yet another comprehensive monetary easing package. Looking forward the central bank's accommodative monetary policy stance may persist in the long run, but it is questionable how much leeway policymakers will be left with if further monetary policy easing becomes necessary.

According to the ECB's September 2019 decision, the interest rate on the deposit facility was lowered to -0.5 per cent; therefore, the room for further interest rate cuts is limited. In parallel with this, the Governing Council decided to introduce a two-tier system for reserve remuneration ${ }^{1}$ and to restart net purchases under its asset purchase programme (APP). In the framework of its existing, open-ended asset purchase programme, the ECB purchases assets at a monthly pace of EUR 20 billion as from 1 November 2019. However, the fact that issuer limits may become effective in the future, hindering further purchases, may pose a problem. As a result of the large-scale asset purchases that commenced in 2015, in the case of several countries - mainly the core countries - the bond portfolio held by the ECB has approached the 33 per cent issuer limit defined by the central bank (Figure 1).

\footnotetext{
${ }^{1}$ In the former system, the interest on the total free reserve holdings deposited with the central bank equalled the deposit facility rate (currently -0.5 per cent), whereas in the new system, banks can achieve a more favourable interest rate at the ECB (currently 0 per cent) on their reserve holdings depending on their minimum reserve.
} 


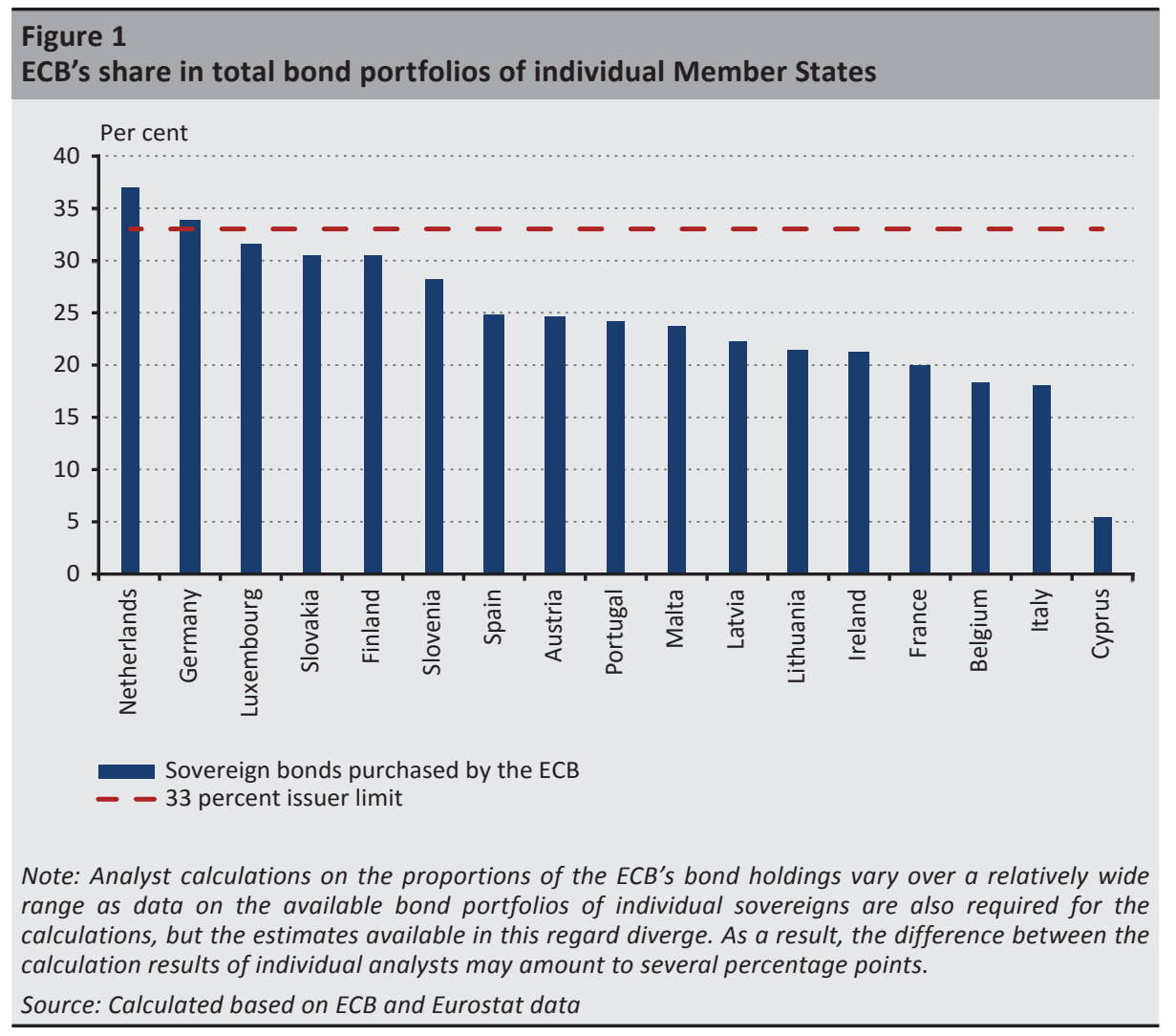

The central bank did not provide specific guidance on the composition of the securities purchased under the restarted asset purchase programme, but upon the announcement Mario Draghi indicated that the ECB would purchase securities in similar proportions to before. Based on historical data, government securities accounted for about 80 per cent of the purchases (Figure 2). Data on the first month of the restarted purchases indicate that the central bank purchases government securities to a lesser degree now, while increasing the share of corporate and covered bonds, which - owing to the smaller share of government paper and the greater share of covered and corporate bond purchases - enables the ECB to run the asset purchase programme for a longer period in its current form. 


\section{Figure 2}

Stock of assets acquired under the APP and future expectations broken down by individual purchase programmes

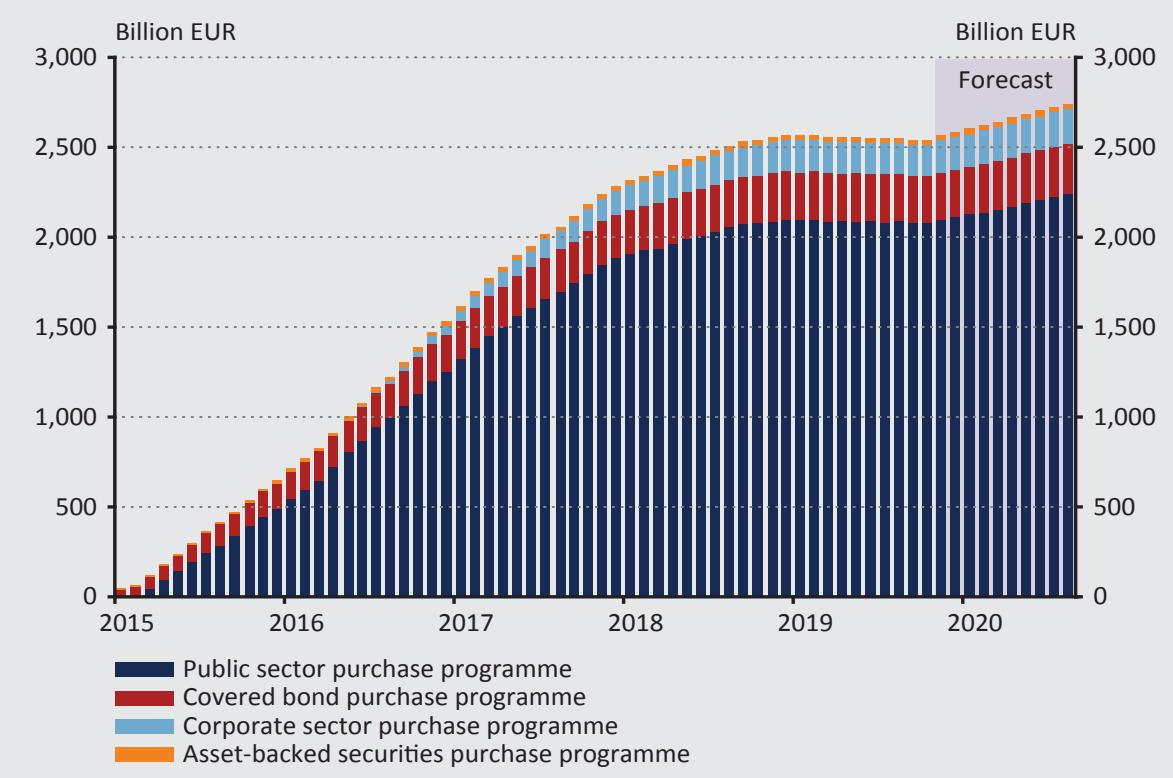

Note: The forecast assumes the same EUR 20 billion monthly purchase rate announced in September 2019 and the same proportion of securities purchases as before. However, data on the first month of the restarted purchases indicate that the central bank reduced its government securities purchases while significantly increasing the share of corporate and covered bonds.

Source: $E C B$, author's projection

The TLTRO-III programme previously announced was also launched in September 2019. Through the targeted longer-term refinancing operation the European Central Bank provides inexpensive long-term financing (liquidity) to credit institutions incorporated in euro area Member States.

\section{Deteriorating economic trends in the euro area}

In the 1990s the current Member States of the euro area grew by 2-3 per cent on average, while inflation hovered around 2 per cent or above. As a result, the nominal GDP growth rate typically moved in the range of 4 to 6 per cent in individual states (Figure 3). With such growth and inflation dynamics, meeting the Maastricht criteria and the relevant fiscal rules left more room for manoeuvre for the fiscal policies of Member States as even a higher budget deficit may not necessarily increase the debt ratio amidst the higher nominal growth rates. 


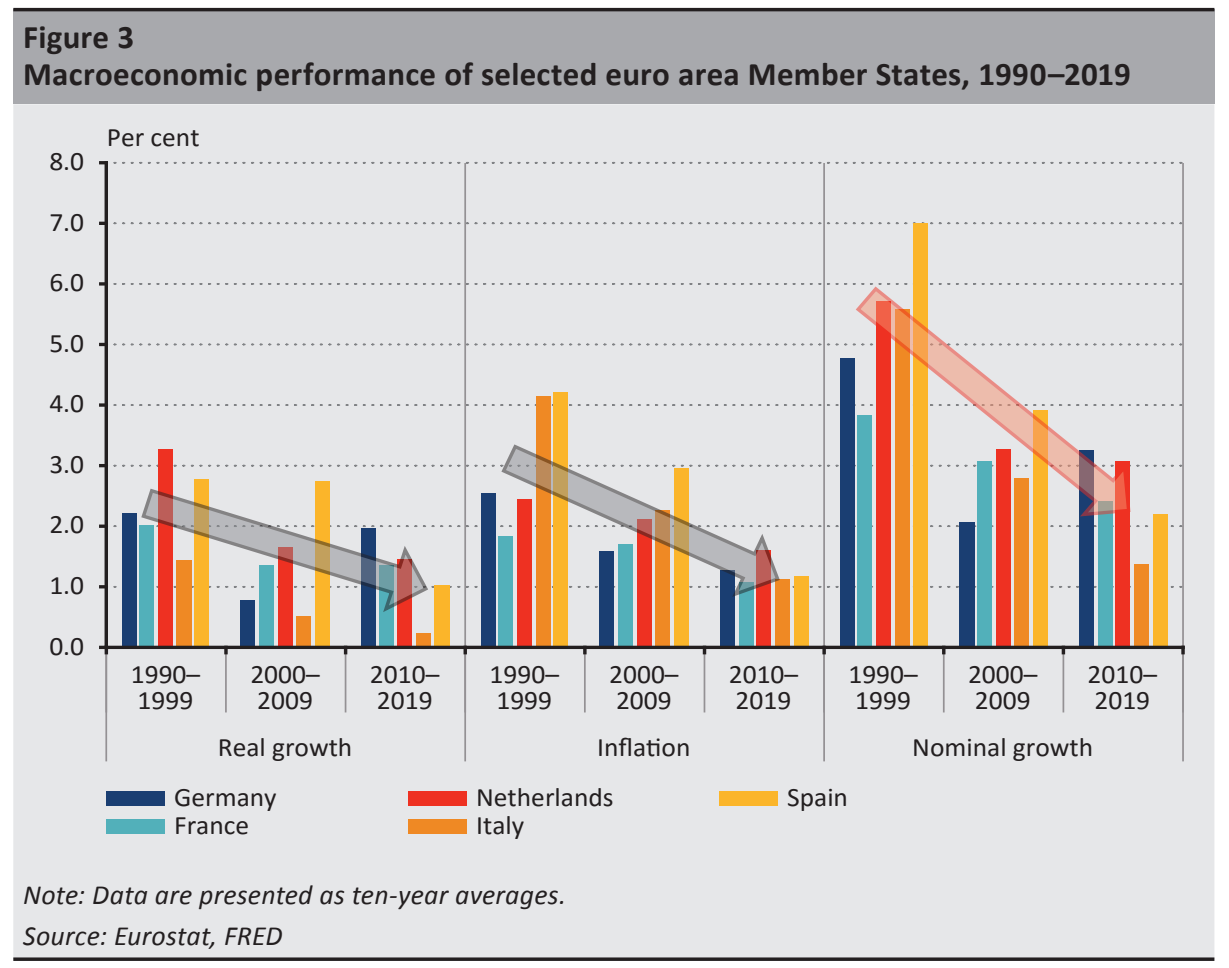

Based on macroeconomic figures, the economy of the euro area continued to prosper in the 2000s as well: Member States grew by 1.5-2 per cent on average, while inflation dropped close to the ECB's inflation target in most Member States. The favourable performance of the euro area, however, was accompanied by a build-up of significant imbalances. As a result of the 2007/2008 crisis and the subsequent debt crisis, euro area growth decelerated considerably along with a material decline in inflation. Lower inflation and decelerating real growth led to a far lower nominal growth rate than before.

It is evident that the macroeconomic performance of the euro area has changed considerably since the 1990s, while the Maastricht criteria adopted in 1992 have remained unchanged to date and, due to the validity of the fiscal rules their principle lived on across the Member States. Besides the fact that the crisis undoubtedly highlighted the deficiencies of these criteria and rules, the changed macroeconomic environment may also warrant a thorough re-think of these conditions. Indeed, the Maastricht criteria were founded on an economic environment where, owing to a higher real growth rate and inflation, nominal growth was also higher. In the current environment, where the nominal growth rate is well below the average of the past two decades, in order to reach - or merely to converge to - the 60 per cent debt ratio a far tighter fiscal policy would be needed than before. Without sufficient fiscal stimulus, however, growth may 
remain restrained, leading to further increases in the debt ratio, which may prompt - mistakenly under the current criteria system - further tightening.

Figure 4 clearly demonstrates that the government debt rule is inconsistent with the deficit rule in the current macroeconomic environment, and therefore the two rules cannot be properly applied together in practice (Lehmann - Palotai 2019 based on Pasinetti ${ }^{2}$ and Buiter ${ }^{3}$ ). The inconsistency between the debt rule and the deficit rule stems from the fact that the 3 per cent deficit prescribed by the Maastricht criteria can only stabilise public debt at 60 per cent when nominal GDP grows by 5 per cent (for more detail about the fiscal rules, see Footnote 7). However, the two rules are inflexible and disregard the changes observed in recent years in macroeconomic trends. In the period between 1998 and 2017, the average nominal growth of the euro area was only 3.1 per cent instead of 5 per cent, which can stabilise government debt at a debt level corresponding to around 100 per cent of GDP if the deficit rule (3 per cent/GDP) is observed. Conversely, given the growth trends of the past 10 years ( 1.8 per cent), which is even lower than before, a deficit of approximately 1.1 per cent would stabilise debt at 60 per cent (Nagy et al. 2020).

\section{Figure 4}

Debt-deficit combinations along various growth paths

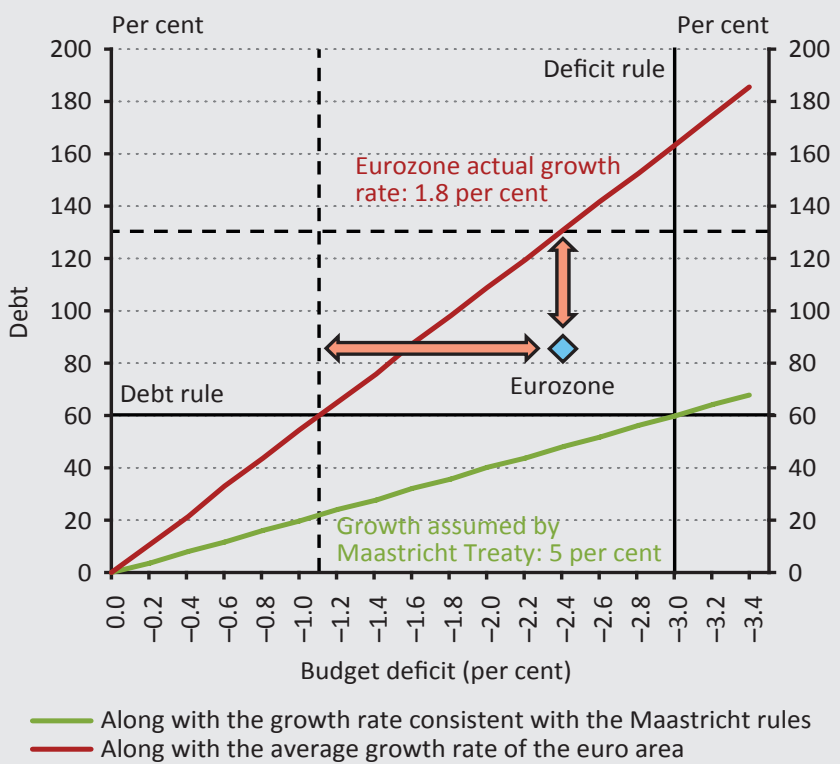

Note: The blue diamond indicates the current deficit and government debt values of the euro area.

Source: $E C B, I M F$

2 Pasinetti, L. (1998): The myth (or folly) of the 3 \% deficit/GDP parameter. Cambridge Journal of Economics, 22(1): 103-116. https://doi.org/10.1093/oxfordjournals.cje.a013701

${ }^{3}$ Buiter, W. H. (1992): Should we worry about the fiscal numerology of Maastricht? CEPR discussion papers no. 668. https://cepr.org/active/publications/discussion_papers/dp.php?dpno=668 


\section{Still room for boosting the economy on the side of fiscal policy}

Besides the legitimacy and suitability of the single currency, debates on the euro area have focused on a single dilemma from the start: is it possible for a monetary union to succeed without a common budget? The 2007/2008 economic crisis brought to the surface the problems stemming from the deficiencies of the euro area's institutional system, but long-term, adequate solutions are yet to be found.

\subsection{Initiative for a common fiscal capacity across the euro area}

The idea of creating a single fiscal capacity at euro area level has been actively discussed but no specific steps have been taken so far. In this regard, we should take note of the Five Presidents' Report ${ }^{4}$ of 2015 (European Commission, European Council, European Parliament, Eurogroup and ECB), and the June 2018 agreement between Angela Merkel and Emmanuel Macron, known as the Meseberg Declaration, which outline a plan for creating a single, euro area level budget from the start of the next seven-year EU budget cycle, i.e. from 2021 (Bagdy et al. 2020).

Finally, the European Commission published the document entitled "Budgetary Instrument for Convergence and Competitiveness" (BICC) on 23 July 2019. ${ }^{5}$ The purpose of the draft is to create a central fund for the countries using the euro, which would enhance the Member States' resilience and competitiveness, and - by supporting structural reforms - foster the convergence of the economies. ${ }^{6}$ While these are important objectives from the perspective of long-term growth and cohesion, optimal monetary and fiscal policy harmonisation and cyclical stabilisation at the euro area level - as discussed in this article - are similarly relevant goals from the same respects. However, during the Eurogroup-level debates of the past few months, the focus was primarily on the support of structural reforms, not on the creation of a genuine cyclical stabilisation instrument, which would be supported primarily by France (Fleming - Khan 2019). For the time being, no agreement has been reached on the exact size of the single budget of the euro area, but it appears likely that - despite Emmanuel Macron's ambitious plans (which amount to several per cent of euro area GDP) - it may only be a negligible amount relative to the size of the currency area; i.e. merely EUR 15-20 billion in 7 years (Bagdy et al. 2020).

According to the proposal, the single budget would be financed from the EU's multiannual financial framework, which may also be supplemented by individual Member States. The exact amount would form part of the negotiations on the entire EU budget. Another debated question of the discourse is whether the single

\footnotetext{
${ }^{4}$ Five Presidents' Report. Plan for strengthening Europe's Economic and Monetary Union as of 1 July 2015. https://europa.eu/rapid/press-release_IP-15-5240_en.htm. Downloaded: 9 December 2019.

${ }^{5}$ Budgetary Instrument for Convergence and Competitiveness. Commission proposes a governance framework for the Budgetary Instrument for Convergence and Competitiveness. https://ec.europa.eu/commission/ presscorner/detail/en/ip_19_4372. Downloaded: 9 December 2019.

${ }^{6}$ In some cases, appropriate structural and competitiveness reforms and policy measures aimed at restructuring the budget might support growth even parallel to reducing the budget deficit.
} 
budget should have independent revenues as well, but according to the current status this appears to be unlikely. Pressured by net contributors - primarily north European countries -, Mario Centeno, President of the Eurogroup, declared that euro area Member States could expect to get back at least 70 per cent of their contributions (Bagdy et al. 2020). This, however, would call into question the point of creation of the single budget, as a significant part of the fiscal capacity would not be redistributed; consequently, the implementation of substantive structural reforms does not appear to be a realistic scenario.

\subsection{Budget proposals submitted by individual Member States for the coming year}

At the September 2019 press conference where the comprehensive easing package of the ECB was announced, Mario Draghi emphasised that the repeated easing of monetary conditions will not be able to stimulate the euro area economy appropriately without an expansionary fiscal stance. As a result of the ECB's easing measures adopted after the crisis, the interest expenditures of individual Member States on government debt declined sharply; thus Member States should be able to loosen their respective fiscal policies with lower funding costs than before. According to Eurostat, in 2012 government interest expenditures still amounted to 3.0 per cent of GDP in the euro area, whereas this ratio dropped to 1.8 per cent of GDP by 2019, and the September announcement of the ECB's new quantitative easing package also points to further declines in interest expenses. That notwithstanding, based on Member States' draft budgetary plans for the coming year, no substantive fiscal stimulus can be expected (Figure 5). This can be attributed in part to the fact that government debt is higher than before the crisis in certain Member States.

\section{Figure 5}

Planned budget balances in selected euro area Member States for 2019 and 2020

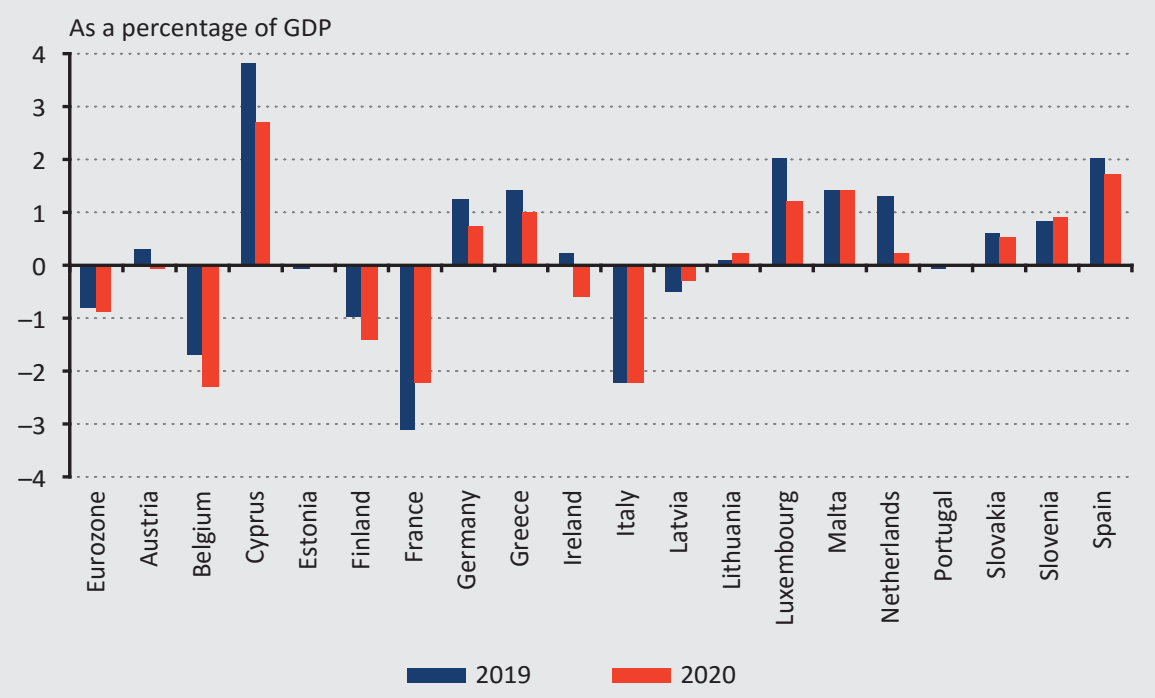

Source: European Commission, based on HSBC (2019) 
The fiscal policy stance can be better captured by the structural primary balance of the budget which, as opposed to the total balance, excludes interest expenses and business cycle effects, and thus it can provide a more accurate view of government spending. However, even the structural primary balance indicates that only minor easing can be expected compared to 2019; the additional fiscal impact expected for 2020 amounts to only 0.4 per cent of GDP in the euro area as a whole (Figure 6). In recent years, fiscal policies have been criticised mainly in those countries that have been accumulating substantial surpluses for years but are nevertheless reluctant to ease their fiscal stance.

The Netherlands shows some openness in this regard: the Dutch government envisages setting up a fund aimed at supporting infrastructure investment and research. At the same time, no substantive change can be expected in Germany; Germany's Minister of Finance, Olaf Scholz declared that the financial position of the German economy is stable, and the government is not expected to provide considerable fiscal stimulus unless a significant economic downturn materialises. Although the German government has recently announced a climate protection fund with a budget of EUR 54 billion, it is planned to be financed through tax levies and the sale of carbon dioxide quotas; therefore no perceivable change is expected in the fiscal policy stance. As regards countries with deficits planned for next year or those recording debt ratios in excess of the desired level - such as Italy, Spain or France -, there is limited space for fiscal stimulus due to the constraints of the Maastricht debt rules.

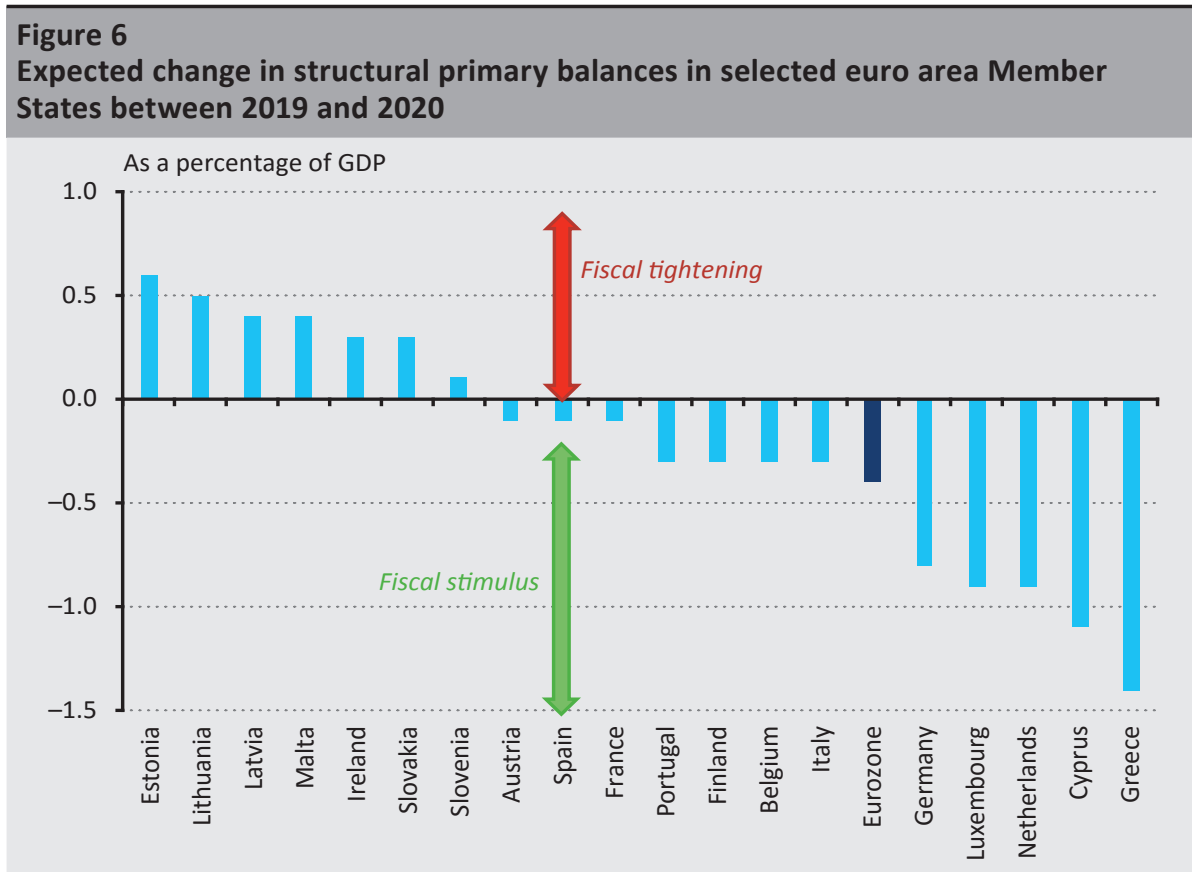

Source: Based on HSBC (2019) 


\subsection{Fiscal policy space in the euro area}

There has been an increased need for fiscal and monetary policy harmonisation in recent periods. With the restart of the European Central Bank's asset purchase programme and the unprecedentedly low interest rate on the deposit facility, the question arises increasingly often both on the part of market participants and policymakers: how long can monetary policy continue to stimulate the economy of the euro area? Numerous prominent policymakers and decision-makers expressed that fiscal policy should be given a greater role in stimulating the economy, and tighter coordination is needed between the two economic policy branches.

The possibility of coordinated fiscal expansion, however, may be constrained both by fiscal rules defined on the basis of the Maastricht criteria and the rules clarifying these criteria. Whereas the Maastricht convergence criteria quantify values that the deficit and debt ratios can only exceed temporarily and in exceptional cases, the clarifications define numeric values that can be quantified and sanctioned even during normal periods. ${ }^{7}$ These rules have become increasingly complex over time, and remain independent of the changes in aggregate demand and the net position of economic sectors; consequently, they disregard the requirements of optimal economic policy coordination even at the national level, and much less at the level of the euro area. It is the net result of several, country-specific effects as to why euro area Member States fail to pursue coordinated fiscal policies which could put the economies concerned on a higher growth path and enable them to approach the inflation target. A key factor is that the expansion would need to start from diverse debt levels, but this is hindered by the Maastricht regulation as for the time being, the debt levels of southern countries significantly exceed the 60 per cent limit (Figure 7).

\footnotetext{
${ }^{7}$ Essentially, the clarifications are intended to ensure that fiscal policy is neutral with regard to the cyclical movement of the economy, that is, the deficit should be close to zero in the cyclical average. The rules enable the budget deficit to stabilise in a weak cyclical position, preferably only through automatic fiscal stabilisers (e.g. unemployment benefit), and to cool the economy if it grows above the trend through the budget surplus (e.g. automatically increasing tax revenues) and minimal "discretional" measures. In addition to neutral cyclical stance, the rules take into account future spending growth such as growing payments due to population ageing, and expect retirement savings in the form of a fiscal surplus. Accordingly, the complex rules consider economic growth to be completely independent; in fact, they intend to separate it from the fiscal policy, and suggest pre-savings using the analogy of households. As we will indicate later, in our opinion these considerations are inadequate. The enforcement of the rules is asymmetric because it does not regard - and accordingly, does not sanction - positive deviations (e.g. overly tight fiscal policies) as errors. Consequently, countries with fiscal space according to the rules cannot be accounted at euro area level to ease their fiscal policies in order to substitute for the missing leeway of countries with more limited means in this regard.
} 


\section{Figure 7 \\ Expected level of debt-to-GDP ratios in euro area countries at end-2019}

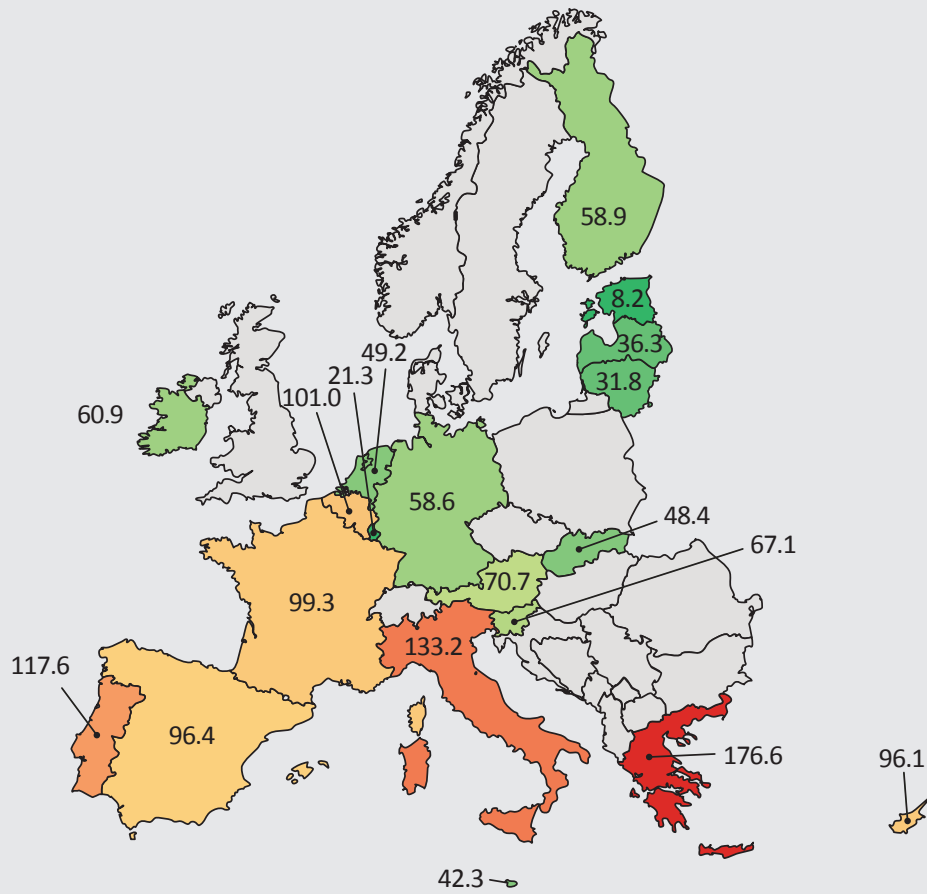

Source: IMF WEO database

Looking at the level of debt-to-GDP ratios we find that the gap between north and south is still considerable in the euro area. Since debt convergence was not achieved in the past decade even under tight fiscal policies, southern European countries - which would need the economic stimulus afforded by a looser fiscal policy - do not currently have sufficient leeway, whereas northern countries which would be capable of providing stimulus - do not wish to use this option.

The tighter fiscal space permitted by the debt level is in part the consequence of the interest burden on outstanding debt and the subdued inflation processes. The moderate debt dynamics typical of euro area countries indicate that the fiscal space was not increased sufficiently after the financial and sovereign crisis. Even though the European Central Bank ensured a low interest rate level, the interest burden on previously accumulated debt exerted significant pressure on euro area budgets (Figure 8). Another difficulty is that even the introduction of various nonconventional instruments failed to boost the economy to such an extent that would have accelerated the reduction of the debt ratio. 


\section{Figure 8}

Cumulative effect of debt-to-GDP ratio drivers in the euro area between 2014 and 2019

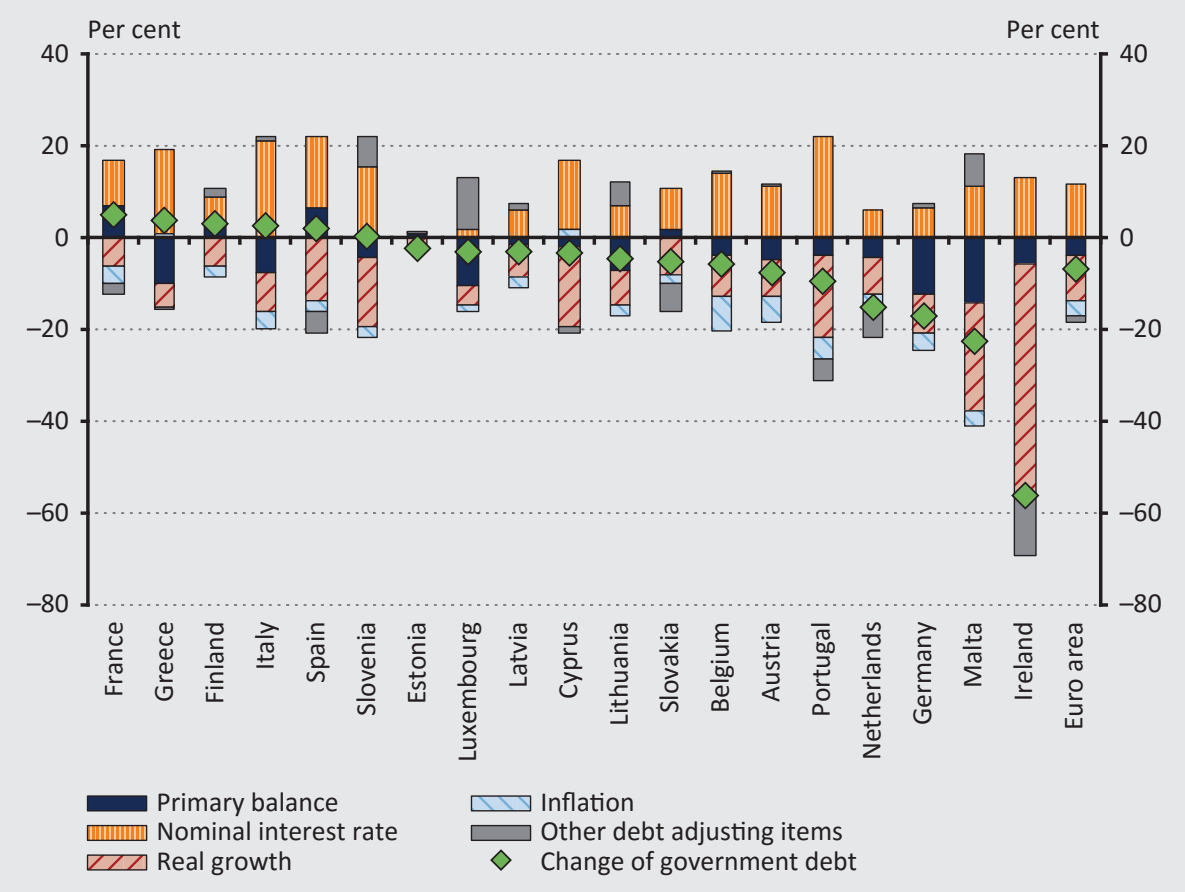

Note: Cumulative values indicate the effects as a percentage of GDP between 2014 and 2019. Negative values should be understood as debt-reducing effects (based on Tóth 2011).

Source: $E C B$

According to Figure 8, real growth wielded the greatest impact on the reduction of government debt: it was capable of offsetting the opposing effect of high debt-service commitments in several countries. In addition, the budget surplus marginally reduced the debt ratio in most Member States, while it may have reduced both potential and actual growth in the Member States concerned. Such crowding-out of growth had a significant adverse effect on Greece and Italy, where public debt rose amidst below-average growth and primary balance surpluses.

According to the (Brussels-Frankfurt-Washington) consensus before the crisis, discretional fiscal policy is generally not conducive to cyclical stabilisation because its decision and implementation mechanism is slow and the removal of the stimulus after the necessary period is often unpopular from a political perspective. Otherwise, policymakers assumed that the cyclical deceleration does not cause a persistent drop in GDP growth. The slow recovery and the USA-EU comparison altered this majority opinion. More recent fiscal multiplier forecasts emphasise 
the state-contingency of the results measured: while the multipliers assumed prior to the crisis were around 0.5 (European Commission, IMF, OECD), after the crisis the values were typically - and at times substantially - above 1 (Blanchard Leigh 2013). Fiscal multipliers show the extent to which GDP grows as a result of an increase in budget expenditures. If the value is above 1, GDP grows faster than the expenditures; in other words, after the unfolding of the spending effects, the debt ratio may decline depending on the initial debt level (it remains unchanged in the case of multiplier is equal to 1 ). If the multiplier is below 1 , the deficit growth (or surplus decrease) may need to be accompanied by other expenditure cuts or tax increases down the road to prevent a debt ratio increase.

This notwithstanding, numerous European policymakers are reluctant to decide on increased spending - which entails an initial increase in deficit or a decrease in the existing surplus -; instead, with a view to reducing the debt ratio, they opt for a stringent fiscal policy. This, however, may also have its disadvantages: if the value of the multiplier is indeed greater than or equal to 1 , the debt ratio may well increase in such a scenario. Another factor to consider is that the market reception of a deficit increase may be unfavourable even if the multiplier is greater than or equal to 1: participants may expect higher interest rates or may attempt to offload government securities, throwing a spanner into debt financing. This consideration raises the problem of the sustainability of debt and the interest rates on government securities.

De Grauwe and Ji (2019) performed calculations to measure the fiscal space available to euro area Member States for increasing deficits in the current interest environment. Using the traditional calculation procedure and based on the difference between interest rates and the growth rate of the economy, they defined the extent to which deficit could be increased with the debt ratio remaining constant. They found that with the exception of Greece and Italy, in 2018 GDP growth exceeded the interest rates on government securities in all euro area countries. Based on this, the budget balances of the Member States could change by as much as minus 3 to 4 per cent compared to the initial, often positive primary balance, without a change in the debt ratio; in other words, they 
could engage in fiscal stimulus of this amount (Table 1). This leeway is particularly important in a period when growth prospects deteriorate.

\begin{tabular}{|c|c|c|c|c|c|}
\hline Country (2019) & Debt-to-GDP & $\mathrm{r}-\mathrm{g}$ & $\begin{array}{c}(r-g) /(1+g) * \\
\text { Debt }\end{array}$ & $\begin{array}{l}\text { Primary } \\
\text { balance }\end{array}$ & Fiscal stimulus \\
\hline Austria & 69.7 & $-3.3 \%$ & $-2.3 \%$ & $1.8 \%$ & $4.1 \%$ \\
\hline Belgium & 101.3 & $-2.4 \%$ & $-2.5 \%$ & $0.8 \%$ & $3.3 \%$ \\
\hline Finland & 58.3 & $-2.9 \%$ & $-1.7 \%$ & $0.5 \%$ & $2.2 \%$ \\
\hline France & 99 & $-1.6 \%$ & $-1.6 \%$ & $-1.5 \%$ & $0.1 \%$ \\
\hline Greece & 174.9 & $4.8 \%$ & $8.4 \%$ & $4.0 \%$ & $-4.3 \%$ \\
\hline Netherlands & 49.1 & $-3.4 \%$ & $-1.7 \%$ & $2.2 \%$ & $3.9 \%$ \\
\hline Ireland & 61.3 & $-6.4 \%$ & $-3.9 \%$ & $1.4 \%$ & $5.4 \%$ \\
\hline Germany & 58.4 & $-3.1 \%$ & $-1.8 \%$ & $1.8 \%$ & $3.6 \%$ \\
\hline Italy & 133.7 & $0.0 \%$ & $0.0 \%$ & $1.2 \%$ & $1.2 \%$ \\
\hline Portugal & 119.5 & $-1.2 \%$ & $-1.4 \%$ & $2.9 \%$ & $4.3 \%$ \\
\hline Spain & 96.3 & $-2.3 \%$ & $-2.2 \%$ & $0.0 \%$ & $2.2 \%$ \\
\hline
\end{tabular}

\subsection{Fiscal policy in a sectoral analytical framework}

Beyond the traditional analytical framework discussed above, the more active role of fiscal policy can be confirmed even more clearly in an analytical framework that takes into account the financial position of main economic sectors and their relations. ${ }^{8}$ The basic concept is fairly simple: the positions of individual sectors are closely related and as such, they must be mutually compatible by necessity. The analogy of a simple market transaction where a seller always needs to find a buyer also holds true at the level of economic sectors: a sector cannot have a surplus without another sector having a deficit, ${ }^{9}$ and a sector can have a zero position only if the total position of all other sectors is zero. In the simplest case, three sectors can be distinguished: non-banking private sector (i.e. households plus corporates), government and rest of the world ${ }^{10}$. At the macro level, the

\footnotetext{
${ }^{8}$ A summary of sectoral interrelationships is also included in Balázs et al. (2020). This section is intended to supplement and provide a more in-depth analysis of this topic.

${ }^{9}$ This necessity, which arises from the principle of accounting correspondence, is often overlooked in modern macroeconomic theories, which tend to attribute macro level outputs to the decisions of individual participants. Even the appearance of behavioural models - which are intended to describe the real behaviour patterns of participants more realistically - could not change this fundamentally. At the same time, the popular, contemporary agent-based models wish to remedy this shortcoming. Kregel and Parenteau, however, base their theories of the long-standing stock-flow consistent models introduced by Godley. A Bank of England study (Barwell - Burrows 2011) connects the results of these two trends. See also Caiani et al. (2016).
}

${ }^{10}$ Kregel (2015), Parenteau (2010) and Godley - Lavoie (2007). 
private sector is typically a net saver, where savings exceed investments $(S>I)$. Although the government sector's taxes and expenditures balance $(T-G)$ and the export-import balance of non-residents $(X-M)$ are more volatile, their net balance necessarily equals the private sector's balance: $(S-I)=(G-T)+(X-M)$. In the typical case, the private sector can only be a net saver if the government or the rest of the world is willing to get indebted to it (Figure 9). If the rest of the world is unwilling to do so, running its own deficit the government will have to remain the "ultimate debtor" (Balázs et al. 2020).

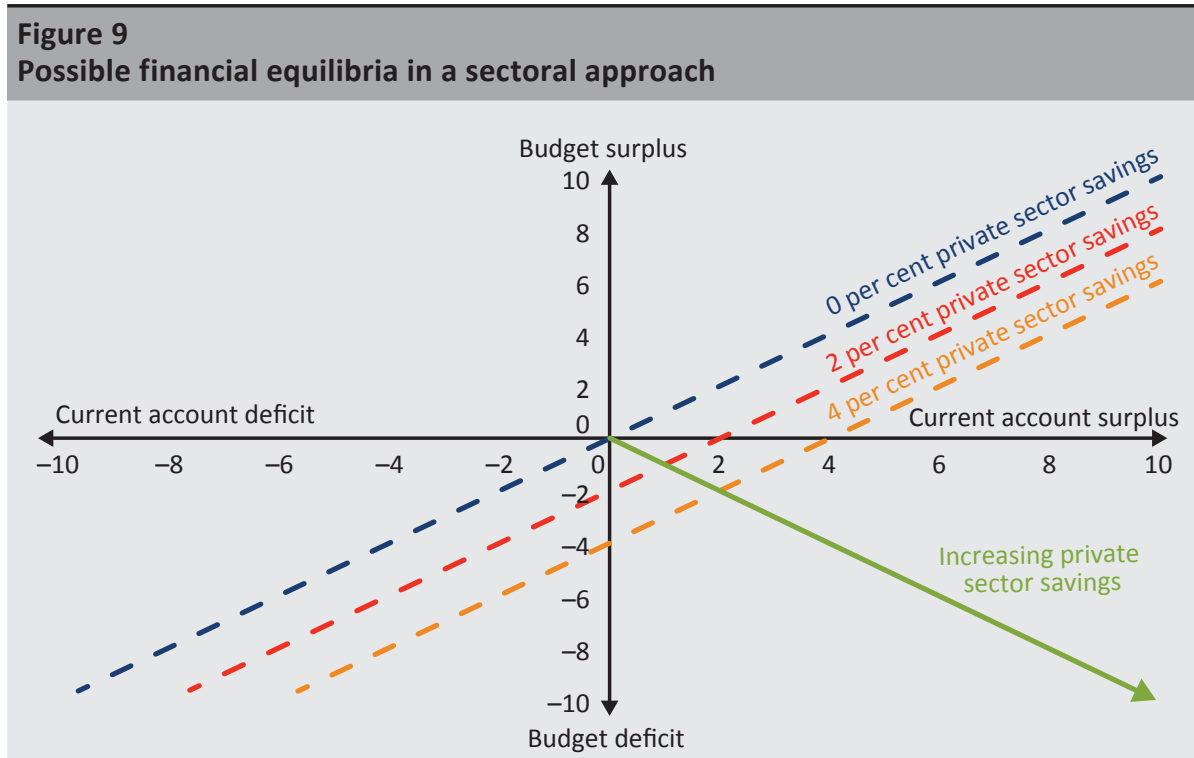

Note: The diagram shows the possible combinations of the positions of the external sector and the fiscal sector given the private sector positions marked with a dotted line. At the centre, all sectors are in equilibrium. A surplus in the private sector demands that the joint position of the other two sectors be a deficit. For example, a current account surplus of 2 per cent and a budget deficit of 2 per cent will allow private savings of 4 per cent. If the rest of the world permits a 2 per cent current account (export) surplus but the budget remains at zero, then the private sector surplus cannot exceed 2 per cent.

Source: Kregel (2015)

The main problem with euro area fiscal rules is that they disregard the relationship between sectoral balances. Similar fiscal rules are applicable to all member countries. Almost all of the countries were forced to make adjustments due to their increased indebtedness and fiscal deficits driven by the financial crisis, even as the private sectors are increasingly net savers as a result of deleveraging. Even disregarding post-crisis deleveraging, it is true in general that fiscal rules prescribe a neutral stance in normal periods or in cyclical average: the deficit cannot exceed 3 per cent and the medium-term fiscal target demands a zero deficit on average (or some surplus, depending on the country concerned, in line with the population 
ageing rate). Thus, if it is true that the private sector is typically a net saver in the euro area, then the economy lacks its own internal dynamics or its own growth model. Therefore, the euro area continues to be export-oriented: it follows the typical strategy of "small, open economies".

As a result, the aggregate demand required for growth can only come from the rest of the world. In a growing global economy where some regions are willing to get indebted, this export-led growth model can actually work, as indeed it worked before the crisis. In the global economy the United States provided the final demand, partly through the budget deficit and partly through private sector indebtedness. ${ }^{11}$ As a result of the crisis, however, growth is weak in the global economy too, and non-resident sectors are also trying to reduce debts accumulated before the crisis. It is therefore doubtful whether the euro area can achieve sufficient growth. Any further increase in net exports demands constraints on wages and investment to such a degree that it hinders domestic growth even more. In this case, without an increase in the fiscal deficit, the measures permitted by EU rules all but hamper growth (Balázs et al. 2020). This phenomenon, called the paradox of thrift by Keynes, could result in stagnation and instability of the euro area. ${ }^{12}$

Leaning towards stagnation, this public governance may be costlier than previously assumed, when economic growth was considered to be a self-sustaining process that does not require any systematic economic stimulus. The supply side was deemed exogenous, i.e. independent of aggregate demand. Besides demographic growth and technological progress, recent research took other factors into account as well that can be influenced by the government (e.g. education, human capital, social capital, research \& development), but typically, these elements did not call for the management of aggregate demand either. This left no role for aggregate demand in the growth models, not even in the endogenous growth models.

In the wake of the crisis, however, more and more recognition is given to the notion - which is already familiar for the generation of economists inspired mainly by Keynes - that without managing aggregate demand an economy is prone to stagnation. Attaining a satisfactory growth rate and the full employment target requires stimulus. ${ }^{13}$ Otherwise, the slow growth rate may endure, meaning investment activity remains restrained and unemployment stabilises at high levels.

\footnotetext{
${ }^{11}$ The wording of Bibow and Terzi (2007) is even stronger: they refer to this growth model as free-riding.

${ }^{12}$ It should be noted that the export-led growth model fails to work in larger regions and much less in the global economy as a whole. As Kregel (2010) pointed out, sooner or later it gives rise to Ponzi-scheme situations in net-deficit running partner countries serving as the markets of export-led economies: they must continue to increase their foreign borrowing in order to meet their FX debt-service commitments (interests) and their trade deficits, which corresponds to the speculative position referred to by Minsky as a Ponzi scheme.

${ }^{13}$ Obviously, the goal is not to increase the budget deficit continuously; instead, the budgetary response should consider the position of the real economy, external demand, the respective positions of individual sectors and the potential afforded by other policy instruments.
} 
Consequently, in response to the poor aggregate demand the supply side becomes endogenously and persistently impaired, and the phenomenon referred to as hysteresis takes hold (for more detail, see Lehmann et al. 2017). If this mechanism is disregarded in the spirit of the pre-crisis consensus and viewed as a trait that is independent of aggregate demand, economic policy will identify it with the maximum growth potential (potential output) of the economy and - in view of the accelerated growth and in fear of inflation - it will put the brakes on the economy. Thus, what started out as a temporary slowdown caused by insufficient demand will become a real, permanent fixture as a result of policy measures (fiscal restraint, central bank interest rate policy). ${ }^{14}$ Experiences of recent years highlighted that analysing the unemployment rate is not enough in itself to determine total capacity utilisation. This is because the unemployment rate may drop below the level previously considered equilibrium if there is a parallel decline in the natural rate of unemployment. In this case, this does not necessarily mean that the economy has attained full capacity utilisation, as also pointed out in a speech by Jerome Powell (2018), in which the current Fed Chairman emphasised that the estimation of the natural rate of unemployment is surrounded by high uncertainty, as indicated by several studies (for example, Orphanides - Williams 2005).

The endogeneity of potential output is hard to confirm empirically because the data reflect the impact exerted on it by the reaction of economic participants. ${ }^{15}$ Before the crisis, the dilemma of policymakers was the assumption that an abovetarget inflation level - even if temporary - poses a direct risk of increasing inflation expectations and excessively high inflation, which were to be avoided. This was also supported by the belief that a potential policy mistake - premature tightening - did not cost anything, as policymakers did not think that potential output would be undermined for a sustained period. After the crisis, however, this assessment was flipped around: while inflation does not return to the target in most countries despite significant central bank stimulus packages and historically low unemployment rates, slow growth leads to persistently low potential growth rates.

Looking at the balances of the sectors we find that the private sector as a whole and non-financial corporations at the euro area level are almost constantly in a net saving position (Figure 10). Although fiscal policy temporarily operated under

\footnotetext{
${ }^{14}$ Most analysts agree that, similar to the estimates of the natural rate of unemployment, the estimates of simultaneous potential output are also surrounded by uncertainty and tend to follow actual growth and unemployment. Ex post revisions, therefore, are extremely frequent: in the light of recent data, the "past" changes continuously. Similarly, the stance of such estimate-based policies may subsequently be assessed in a new light: an economic policy previously considered stimulating may appear neutral or even restrictive later on, and vice versa.

${ }^{15}$ A classical reference is an article by Okun (1973), in which the author proposes a high-pressure economic policy to reverse stagnation and growing unemployment. After the financial crisis, this concept was reiterated by Ball (2015). See also Blanchard - Summers (1986). In Europe, the concept had always been present, after Kaldor, in Keynesian and post-Keynesian literature, e.g. Ledesma - Thirlwall (2000), Fatas Summers (2018), Heimberger - Kapeller (2017), Heimberger (2019).
} 
greater deficits after the crisis, it is now nearly in equilibrium at the level of the euro area. Private sector savings, therefore, can only be offset by the increased deficit of the rest of the world. Obviously, there are significant differences in the sectoral breakdown between individual countries. The cross-country variation observed between north and south is particularly prominent: while in Germany and the Netherlands, for example, both the private sector and the government

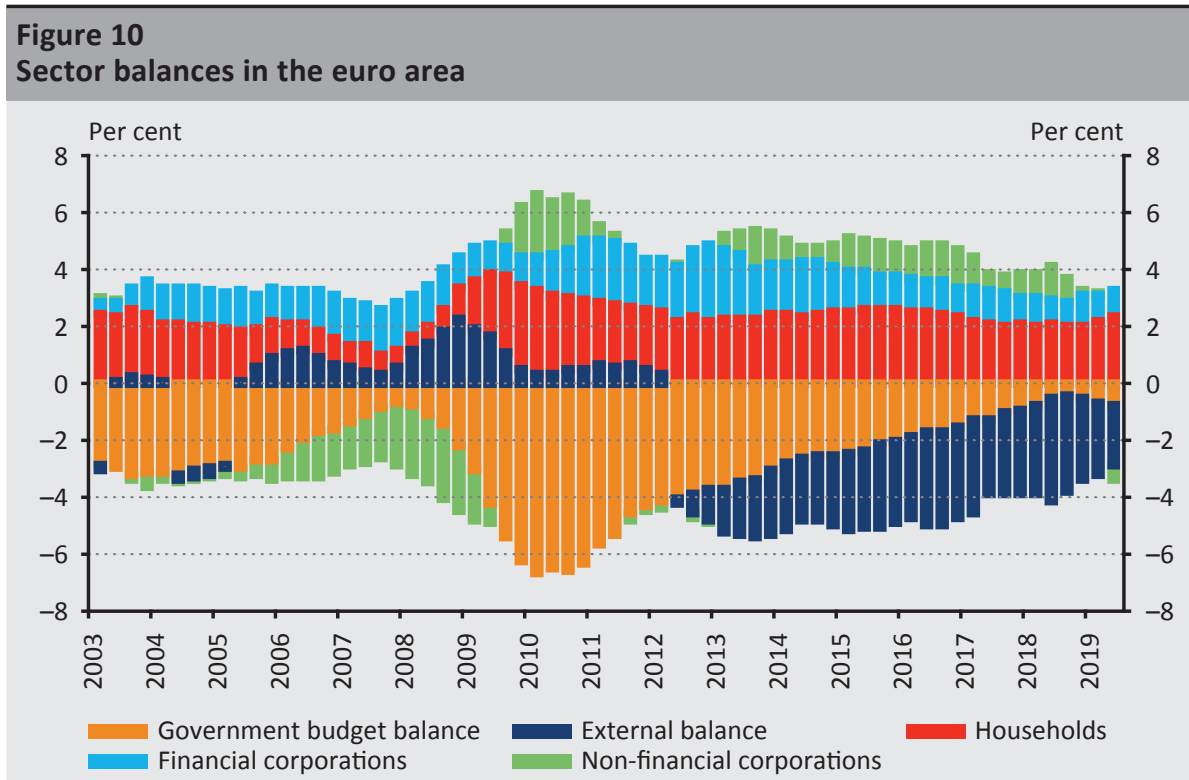

Note: Four-quarter rolling average. In the case of the external balance, negative values indicate the indebtedness of non-residents; i.e. the surplus of euro area financial accounts.

Source: $E C B$

sector have a surplus, in Italy and Spain private sector savings are partly offset - in addition to non-residents - by the budget deficit.

Before the crisis, investment activity was buoyant in the Spanish economy; a substantial part of the capital required was provided by non-residents. Nonfinancial corporations implemented major investments in the pre-crisis period (30 per cent of GDP in 2007), while households reduced their savings concurrently (Figure 11). As a result of the private sector's net deficit position, the Spanish economy recorded a current account deficit approaching 10 per cent of GDP, which was a consequence of substantial capital and goods imports. 
During the crisis, in order to smooth the negative effects of the downturn, the Spanish economy temporarily ran a significant budget deficit. After the crisis, however, a complete reconfiguration took place in the sectoral balances of Spain: both the sector of non-financial corporations and households became net savers. As a result, there was a sharp decline in investment as a percentage of GDP;

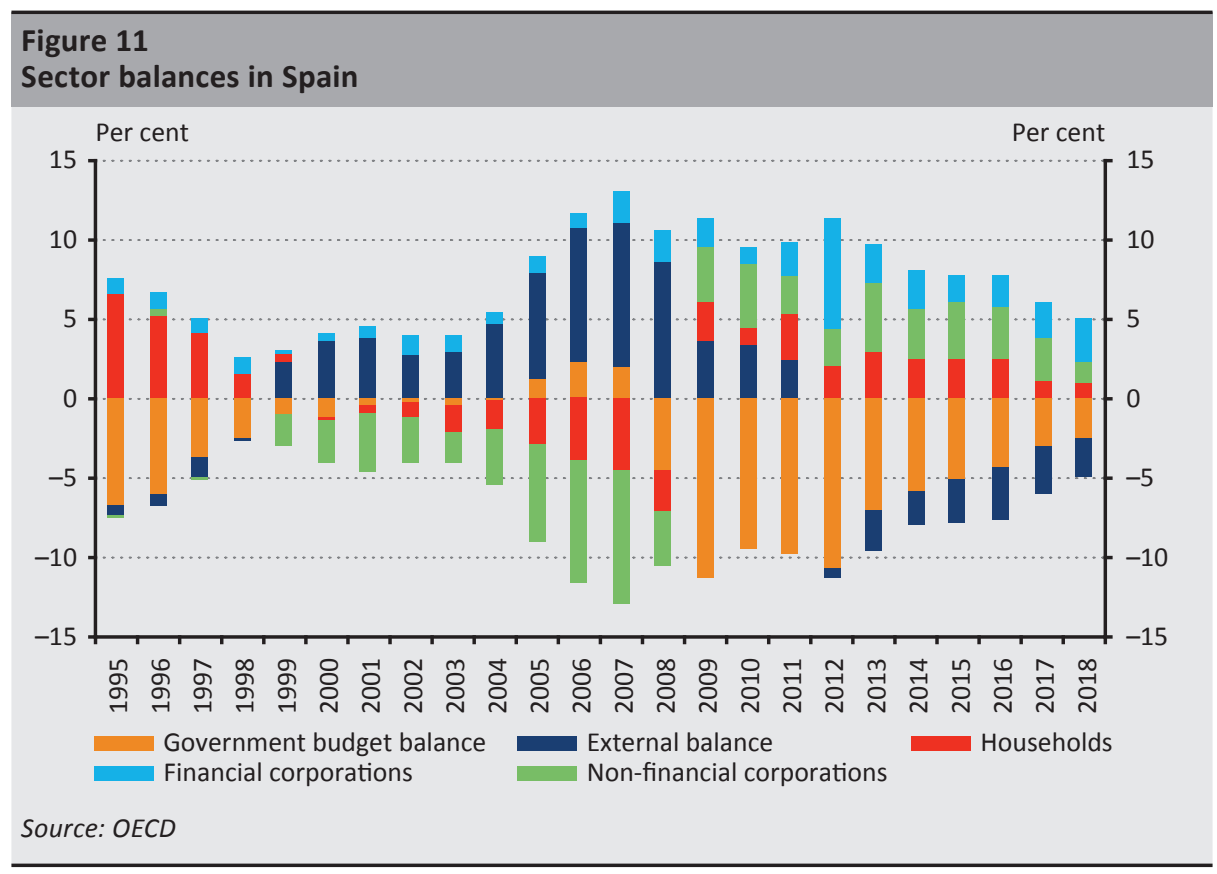

compared to the average of the previous decade, the investment ratio was 3-4 percentage points lower. Parallel to this, the previous deficit of the balance of payments turned into a surplus, while the level of the budget deficit was gradually reduced.

In Germany, the private sector took a net saving position before 2008. In the period preceding the crisis, all sub-sectors of the private sector were in a net saving position, which was accompanied by a high surplus in net exports (Figure 12). This structure of the sector balances accurately reflects the emerging view of the German economy; namely, in the context of a substantial trade surplus, the savings of German households expand by 5 per cent of GDP. The maintenance of the net saving position of non-financial corporations was permitted by the investment ratio relative to GDP, which had been on a continuous decline since the 1990s, thereby contributing to the deceleration in potential output growth. 
In the period following the financial crisis, the German financial system was engaged in financing and/or investment. After 2012, a significant change was also observed in sector balances, with an impact on the euro area as a whole. First and

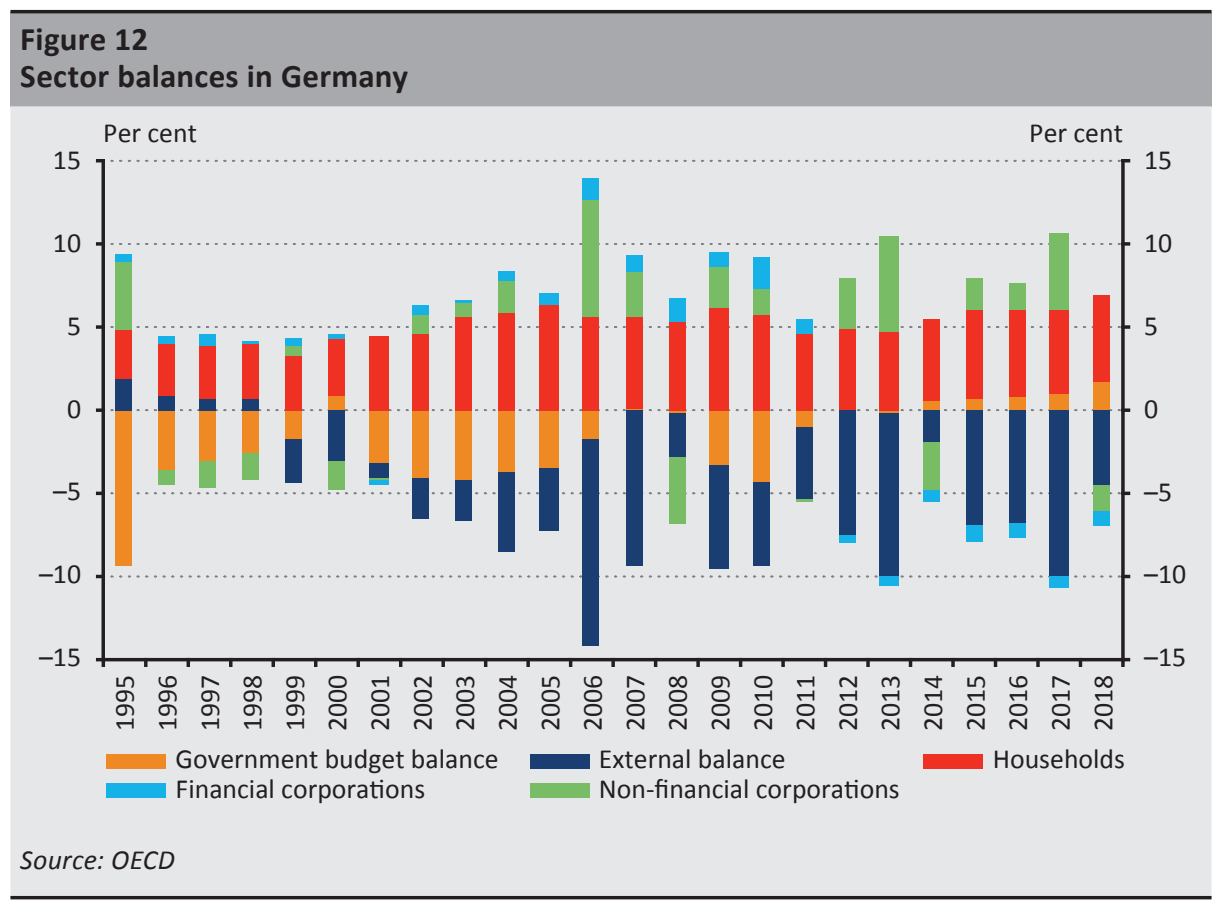

foremost, we should note the setting up of stringent, surplus budgets, which are significant even as a percentage of GDP. As a result, exports remained the most important driver of the economy, which is also supplemented by the net output of German financial enterprises. Since non-financial enterprises typically remain net savers even after the crisis, GDP-proportionate investment continues to fall short of the average of the 1980s and 1990s.

Owing to the fiscal rules that are based on the strict Maastricht criteria and the decelerating global economy, perceivable growth can only be maintained through substantial private indebtedness. Due to the accounting interrelationship between sectoral balances, any economic policy or regulatory measure can inevitably only be implemented at the price of a trade-off between the sectors. Given the Maastricht debt and deficit rules, the structure of the euro area's economic governance does not enable the pursuit of growth-conducive fiscal policies under the current economic conditions. This necessarily implies that only export-led growth can be an alternative growth model without the build-up of severe financial stability risks in the private sector. This model worked fairly well in the past both in Germany and 
the Netherlands, but its sustainability is called into question by the protectionist economic policy of the United States and the decelerating Chinese economy.

Adherence to the current fiscal rules exerts a negative impact on aggregate demand. The substantial trade surplus also affects the competitiveness of enterprises, as the financing provided by non-residents can only be maintained with subdued wage growth in an environment of fiscal austerity. As a result, domestic demand will be increasingly deficient, leading to weaker growth and prompting corporations to invest even less which, owing to the subdued growth, calls for even more fiscal tightening if the debt ratio is to be maintained.

\section{Position of EU policymakers on coordination between economic policy branches}

Mario Draghi, whose presidency of European Central Bank ended at the end of October 2019, had regularly emphasised the significance of fiscal policy in his speeches even before. At the regular annual forum of central bankers and academicians held in Sintra in June 2019, however, Mario Draghi stressed the importance of fiscal policy even more decisively. The then ECB President underlined that while monetary and fiscal policy cooperated in the first phase of the crisis to decelerate and reverse the economic downturn, thereafter the stance of monetary and fiscal policy decoupled in the euro area and, as opposed to the United States, the euro area fiscal stance turned contractionary. At the moment, added Mario Draghi, monetary and fiscal policy are not in balance, which contributes to disinflation. Therefore, a common fiscal framework should be established, which allows for sufficient fiscal stabilisation across the euro area. This is all the more needed because while there are countries which would have sufficient fiscal space even under the current rules, fiscal expansion spillovers in the countries without such fiscal space may be overly limited. ${ }^{16}$

In one of his later speeches Draghi emphasised that the absence of a clear, common lender of last resort (backstop) behind the European Stability Mechanism (ESM) with respect to the government securities market poses a problem in the smoothing of the geographical differences in the cycles within the euro area; moreover, there is no European deposit insurance scheme in place and for the time being, there has been little meaningful progress on fiscal policy coordination. With respect to cyclical stabilisation at the euro area level Mario Draghi pointed out that equilibrium real interest rates have trended downwards in recent years. In such an environment the proportions of the cooperation between fiscal and

\footnotetext{
${ }^{16}$ Twenty Years of the ECB's monetary policy. Speech by Mario Draghi, President of the ECB, ECB Forum on Central Banking, Sintra, 18 June 2019. https://www.ecb.europa.eu/press/key/date/2019/html/ecb. sp190618 ec4cd2443b.en.html. Downloaded: 9 December 2019.
} 
monetary policy change. A more active fiscal policy may ease the stabilisation burden on monetary policy, and adverse side effects may also moderate. However, in Draghi's opinion this has not been recognised at all in the euro area, as is clearly evident from the data: between 2009 and 2019 the average primary balance was -5.7 per cent for Japan and -3.6 per cent for the US, but 0.5 per cent for the euro area. According to Draghi, central banks have an obligation to speak up if other policies may help achieve their goals faster. ${ }^{17}$

In Draghi's assessment, the euro area has a mildly expansionary fiscal stance at present, but in view of the weakening economic outlook and downside risks, countries with fiscal space should act in a more effective and timely manner. In addition, he pointed out that all successful monetary unions have a central fiscal capacity. This is why it is very important for the euro area to have sufficient capacity that could be used as a kind of countercyclical stabiliser. At present the complex nature of the adequate coordination of decentralised fiscal policies poses a significant problem ${ }^{18}$.

In his farewell remarks closing his ECB Presidency, Mario Draghi noted that the euro area was built on the principle of monetary dominance, which requires monetary policy to focus primarily on price stability and never to be subordinate to fiscal policy. However, this does not preclude communicating with governments when it is clear that mutually aligned policies would deliver a faster return to price stability. The building of a capital market union would reduce the stabilisation tasks that need to be addressed by the central fiscal capacity ${ }^{19}$.

In her opening statement to the Economic and Monetary Affairs Committee of the European Parliament in September 2019 Christine Lagarde, the later President of the European Central Bank emphasised that cooperation with fiscal policy would make an important contribution to the cyclical stabilisation of the euro area economy and that the creation of a centralised fiscal capacity would be useful ${ }^{20}$. She also stressed that current fiscal rules should be simplified and become more effective. In a later statement she stressed, similarly to her predecessor, that economies with fiscal space should pursue more active fiscal policies. As opposed to Draghi who had always been reluctant to name specific countries, she openly

${ }^{17}$ Stabilisation policies in a monetary union. Speech by Mario Draghi, President of the ECB, at the Academy of Athens, Athens, 1 October 2019. https://www.ecb.europa.eu/press/key/date/2019/html/ecb. sp191001_1 5d7713fcd1.en.html. Downloaded: 9 December 2019.

${ }^{18}$ Introductory Statement, Press Conference. Mario Draghi, President of the ECB, Frankfurt am Main, 24 October 2019. https://www.ecb.europa.eu/press/pressconf/2019/html/ecb.is191024 78a5550bc1.en.html. Downloaded: 9 December 2019.

${ }^{19}$ Remarks by Mario Draghi, at the farewell event in his honour. Frankfurt am Main, 28 October 2019. https://www.ecb.europa.eu/press/key/date/2019/html/ecb.sp191028 7e8b444d6f.en.html. Downloaded: 9 December 2019.

${ }^{20}$ Draft Report on the Council recommendation on the appointment of the President of the European Central Bank. European Parliament, Committee on Economic and Monetary Affairs, 29 August 2019. http://www. europarl.europa.eu/doceo/document/ECON-PR-639816_EN.pdf. Downloaded: 9 December 2019. 
referred to Germany and the Netherlands as economies that should adopt fiscal easing in order to stimulate investment. As a critical remark she noted that there is insufficient solidarity in the euro area: despite sharing a currency, there is no common budgetary policy (Lagarde 2019).

Similarly, among the policymakers of the ECB the Dutch Klaas Knot also mentioned in October 2019 that there is a need to strengthen the Economic and Monetary Union (EMU) as without additional action, growth stimulating monetary policy measures may become constrained. In his opinion, monetary and fiscal policy should move in the same direction as there is mounting evidence that monetary policy can reach its goals faster and with fewer side effects if it is aligned with fiscal policies (Knot 2019b). Luis de Guindos, Vice-President of the European Central Bank is also of the opinion that the euro area needs a centralised and independent fiscal instrument as the existing framework is ineffective and not complementary to the ECB's monetary policy. He argues that a centralised instrument would also provide support to national fiscal policies (Guindos 2019).

Several policymakers have criticised the monetary easing package announced by the European Central Bank in September 2019 and some of them emphasised that fiscal policies should provide stronger support to monetary policy. In addition, a number of policymakers pressed the case for the creation of a substantive fiscal capacity at the euro area level, which would be capable of smoothing the cycles across the euro area and hence, stabilising the euro area economy over the long term. For the time being, however, the economic policy discourse has not yielded any agreement or support on the part of countries where such capacity is actually available. Moreover, the debate between the branches of economic policy is expected to drag on. Since a more active role of fiscal policy or a common fiscal capacity would result in the redefinition of current rules, we cannot expect a fast reform or support to monetary policy. ${ }^{21}$

\section{Summary}

In recent decades, there has been a considerable moderation in the euro area both in terms of economic growth and inflation processes. As a result, some of the quantified values specified in the Maastricht criteria and incorporated into the fiscal rules have become practically invalid today, which causes tensions in economic

\footnotetext{
${ }^{21}$ This outlook is supported by the November 2019 response of Marco Buti and his colleagues of the Commission to the criticisms raised in relation to the Commission's estimate on potential output, which suggests that, in their opinion, a considerable modification of the methodology is neither possible nor really necessary (Buti et al. 2019). Although Buti's mandate as Director General of the Commission ended at the end of last year, we assume that - for the time being - the article cited continues to reflect the professional consensus within the institution. However, after his resignation Buti (2020) admits that, because of Greece's fiscal crisis, they also viewed the other countries through "fiscal lenses", which Buti refers to as a mistake. He also calls for a more active role for fiscal policy in addition to monetary policy.
} 
policy decision-making. Despite the ultra-loose monetary policy stance following the crisis, in several regions monetary policy failed to provide sufficient support to private sector investment and aggregate demand, which has cast an even sharper light on the difficulties in recent years. Growing conflicts have recently come to the surface even among the policymakers of the ECB in respect of the optimal allocation of tasks between the branches of economic policy. Several policymakers have criticised the latest monetary easing package announced by the European Central Bank in September 2019 stressing that monetary policy has reached its boundaries, and in the current environment any further steps can provide little stimulus to the economy. Parallel to this, more and more policymakers emphasised that fiscal policy should provide stronger support to monetary policy and hence, economic growth. In addition, an increasing number of policymakers are pressing the case for the creation of a substantive fiscal capacity at the euro area level, which would be capable of smoothing the cycles across the euro area and hence, stabilising the euro area economy over the long term.

Although the fiscal rules have been revised and there is some progress in institutional reforms, for the time being no real willingness has been shown by economic policy to implement any of the measures. The budget proposals submitted by individual Member States for the coming year indicate that no substantial fiscal stimulus can be expected in the euro area in the near future either. In addition to the resistance of some Member States, fiscal rules founded on the Maastricht principle also limit the possibility of coordinated fiscal expansion. Moreover, the fact that euro area fiscal rules disregard the interrelationships between individual economic sectors also poses a problem. At present, the pro-cyclical economic policy of southern euro area countries does not provide the means to prevent and manage a future crisis. By contrast, while the economic conditions of northern states would be able to support a coordinated fiscal expansion, the Member States concerned have no such intentions, even though some analyses pointed out that the budget balance of most Member States would provide sufficient space for significant easing without changing the debt ratio. Looking ahead, it may be expedient to rethink the Maastricht criteria - which are still in effect -, the fiscal rules and, concurrently, the allocation of tasks between the branches of economic policy.

\section{References}

Bagdy, Á. - Füstös, K. - Szalai, Z. (2020): What's next for the euro area: directions of institutional development. In: Virág, B. (ed): Long-term sustainability and the euro - How to rethink the Maastricht criteria? Magyar Nemzeti Bank, pp. 121-146.

Balázs, F. - Lehmann, K. - Szalai, Z. (2020): The shortcomings of the Maastricht Criteria. In: Virág, B. (ed): Long-term sustainability and the euro - How to rethink the Maastricht criteria? Magyar Nemzeti Bank, pp. 91-120. 
Ball, L. (2015): Monetary Policy for a High-Pressure Economy. https://pdfs.semanticscholar. org/3ecf/cdff1148c703d50a1e992290867e007a96db.pdf. Downloaded: 9 December 2019.

Barwell, R. - Burrows, O. (2011): Growing Fragilities? Balance Sheets in the Great Moderation. Financial Stability Paper No 10, Bank of England. https://www.bankofengland. co.uk/-/media/boe/files/financial-stability-paper/2011/growing-fragilities-balance-sheetsin-the-great-moderation. Downloaded: 9 December 2019.

Bibow, J. - Terzi, A. (2007): Introduction: Euroland and the World Economy - Global Player or Global Drag? In: Bibow, J. - Terzi, A.: Euroland and the World Economy - Global Player or Global Drag? Macmillan, pp. 1-11. https://doi.org/10.1057/9780230377554_1

Blanchard, O. - Summers, L.H. (1986): Hysteresis and the European unemployment problem. In: Fisher, S. (ed.): NBER Macroeconomics Annual 1986, Vol. 1. MIT Press, pp. 15-90. https://doi.org/10.3386/w1950

Blanchard, O. - Leigh, D. (2013): Growth forecast errors and fiscal multipliers. IMF Working Papers, No. 13/1, Washington, D.C. https://doi.org/10.5089/9781475576443.001

Buti, M. - Carnot, N. - Hristov, A. - Mc Morrow, K. - Roeger, W. - Vandermeulen, V. (2019): Potential output and EU fiscal surveillance. VOXEU, 23 September. https://voxeu.org/ article/potential-output-and-eu-fiscal-surveillance. Downloaded: 31 January 2020.

Buti, M (2020): Riding through the storm: Lessons and policy implications for policymaking in EMU. VOEXEU, 12 January. https://voxeu.org/article/lessons-and-policy-implicationspolicymaking-emu. Downloaded: 5 February 2020.

Caiani, A. - Godin, A. - Caverzasi, E. - Gallegati, M. - Kinsella, S. - Stiglitz, J. E. (2016): Agent based-stock flow consistent macroeconomics: Towards a benchmark model. Journal of Economic Dynamics and Control, 69(August): 375-408. https://doi.org/10.1016/j. jedc.2016.06.001

De Grauwe, P. - Ji, Y. (2019): Rethinking fiscal policy choices in the euro area. VOX, CEPR Policy Portal, 14 October. https://voxeu.org/article/rethinking-fiscal-policy-choices-euro-area. Downloaded: 9 December 2019.

Fatas, A. - Summers, L.H. (2018): The permanent effects of fiscal consolidations. Journal of International Economics, 112(May): 238-250. https://doi.org/10.1016/j. jinteco.2017.11.007

Fleming, S - Khan, M. (2019): EU finance ministers approve separate 'eurozone budget' tool. Financial Times, 10 October. https://www.ft.com/content/1cf66b48-eb35-11e9-a2403b065ef5fc55. Downloaded: 9 December 2019.

Godley, W. - Lavoie, M. (2007): Monetary Economics: An Integrated Approach to Credit, Money, Income, Production and Wealth. London: Palgrave MacMillan. 
Guindos, L. (2019): Euro Area Needs a Central Fiscal Instrument, ECB's Guindos says. Bloomberg, 26 October. https://www.bloomberg.com/news/articles/2019-10-26/euroarea-needs-a-central-fiscal-instrument-ecb-s-guindos-says. Downloaded: 9 December 2019.

Heimberger, P. - Kapeller, J. (2017): The performativity of potential output: pro-cyclicality and path dependency in coordinating European fiscal policies. Review of International Political Economy, 24(5). https://doi.org/10.1080/09692290.2017.1363797

Heimberger, P. (2019): What is structural about unemployment in OECD countries. Review of Social Economy. https://doi.org/10.1080/00346764.2019.1678067

HSBC (2019): Eurozone fiscal policy - More a water pistol than a bazooka. Report of HSBC Global Research, 22 October.

Knot, K. (2019a): Dutch governor attacks ECB's new stimulus. Central Banking, 13 September. https://www.centralbanking.com/central-banks/monetary-policy/monetary-policydecisions/4429901/dutch-governor-attacks-ecbs-new-stimulus. Downloaded: 9 December 2019.

Knot, K. (2019b): Opening remarks by Klaas Knot. At the panel "The Advanced Countries: Economic Challenges for the Medium Term" during the G30 34th International Banking Seminar, Washington, 20 October. https://www.dnb.nl/en/binaries/AC_tcm47-386006. pdf. Downloaded: 9 December 2019.

Kregel, J. (2010): An Alternative Perspective on Global Imbalances and International Reserve Currencies. Levy Economics Institute of Bard College. http://www.levyinstitute.org/pubs/ ppb_116.pdf. Downloaded: 9 December 2019.

Kregel, J. (2015): Europe at the crossroads: financial fragility and the survival of the single currency. Levy Economics Institute of Bard College. http://www.levyinstitute.org/pubs/ pn_15_1.pdf. Downloaded: 9 December 2019.

Lagarde, C. (2019): Lagarde hits out at Germany and Netherlands on public spending. Financial Times, 30 October. https://www.ft.com/content/eb8dae8c-fb14-11e9-a35436acbbb0d9b6. Downloaded: 9 December 2019.

Ledesma, L. - Thirwall, A. (2000): Is the natural rate exogenous? BNL Quarterly Review, 53(215): 433-445.

Lehmann, K. - Szalai, Z. - H. Váradi, B. (2017): Új szelek a gazdaságpolitikában (New Winds in Economic Policy). Szakmai cikk (Article), Magyar Nemzeti Bank. https://www.mnb.hu/ letoltes/lehmann-kristof-szalai-zoltan-h-varadi-balazs-mnbhonlapra.pdf. Downloaded: 9 December 2019. 
Lehmann, K. - Palotai, D. (2019): Maastricht criteria: 20th century rules in the 21st century. Szakmai cikk (Article), Magyar Nemzeti Bank. https://www.mnb.hu/letoltes/lehmannpalotai-maastricht-criteria-20th-century-rules-in-the-21st-century.pdf. Downloaded: 9 December 2019.

Nagy, M. - Virág, B. (2017): Felzárkózás az eurozónában - csakis megfelelő felkészültséggel teljesithető. (Convergence in the Euro Area: Achievable Only After Appropriate Preparations). Szakmai cikk (Article), Magyar Nemzeti Bank. https://www.mnb.hu/letoltes/ nagy-marton-virag-barnabas-felzarkozasi-az-eurozonaban-frissitett.pdf. Downloaded: 9 December 2019.

Nagy, O. - Szalai, Z. - H. Váradi, B. (2020): The Maastricht criteria - conditions and assumptions. In: Virág, B. (ed): Long-term sustainability and the euro - How to rethink the Maastricht criteria? Magyar Nemzeti Bank, pp. 19-38.

Okun, A. (1973): Upward Mobility in a High-Pressure Economy. Brookings Papers on Economic Activity, 1973(1): 207-261. https://doi.org/10.2307/2534087

Orphanides, A. - Williams, J. C. (2005): The Decline of Activist Stabilization Policy: Natural Rate Misperceptions, Learning and Expectations. Journal of Economic Dynamics and Control, 29(11): 1927-1950. https://doi.org/10.1016/j.jedc.2005.06.004

Parenteau, R. (2010): Minsky and the Eurozone Predicament: Transcending the Dismal Science. Presented at the 19th Annual Hyman P. Minsky Conference, After the CrisisPlanning a New Financial Structure, New York, N.Y., April 15.

Powell, J.H. (2018): Monetary Policy in a Changing Economy. Speech at Jackson Hole conference, Wyoming, 24 August. https://www.federalreserve.gov/newsevents/speech/ powell20180824a.htm. Downloaded: 9 December 2019.

Tóth G., Cs. (2011): Adósságdinamika és fenntarthatóság (Debt dynamics and sustainability). Statisztikai Szemle (Hungarian Statistical Review), 89(12): 1242-1268.

Weidmann, J. (2019): ECB Governing Council has gone too far. Interview with the BILD newspaper, 14 September. https://www.bundesbank.de/en/press/interviews/-ecbgoverning-council-has-gone-too-far--806872. Downloaded: 9 December 2019. 